\title{
A PRAGMATIC ANALYSIS OF DIRECTIVE UTTERENCE USED BY ENGLISH TEACHER AT MADRASAH ALIYAH PONDOK PESANTREN AL-KAMIL
}

\author{
${ }^{1}$ Moh Rizky Aziz, ${ }^{2}$ Moh Iqbal Firdaus, ${ }^{3}$ Aris Gumilar \\ English Education Study Program \\ Teachers Training and Education Faculty \\ Muhammadiyah University of Tangerang \\ J1.Perintis Kemerdekaan 1/33 Cikokol, Tangerang - Indonesia \\ Email: Muhammad.rizky.aziz@gmail.com, fmohiqbal@gmail.com . \\ arisgumilar@yahoo.com
}

\begin{abstract}
This research was intended to describe types of speech acts performed by English lecturers in learning process at Madrasah Aliyah Pondok Pesantren Al-Kamil. This research was descriptive qualitative. The data of this research were the English utterances performed by English Teachers. The researcher obtained the data by means of observation technique. In observation technique the researcher used recording instruments, sound recorder, to record the classroom dialogues. Next, the researcher writes some data into note to as a additional data report The researcher analyzes the directive speech act in this research using Kreidler's theory (1998). Based on the observation, the researcher found three types of directive speech act. They are command/order, request, Warning or prohibitation. In conclusion, the researcher found directives speech act from observation are 3 utterances are command/order (2,80\%), 2 utterances are requesting (1,87\%), 1 utterance is warning (0,93\%), and 101 utterances are unidentified $(94,39 \%)$
\end{abstract}

Keywords : English Teacher, Directive Speech Act, Descriptive Study 


\section{A. INTRODUCTION}

Language has an important role for human to make an interaction each other. Without language, a person cannot convey their mind, opinion, concept or feeling. The function of language is to communication. Communication is successful not when hearers recognize the linguistic meaning of the utterance, but when they infer the speaker's "meaning" from it (Sperber and Wilson in Allan, 1986, p. 23). It means that one utterence has various kinds of meaning depends on situation and context when the communicating is running.

Communication in education is important thing because there are feedback between students and teacher. according to Santrock (2008), three main aspect of communication in learning, such as speaking, hearing, and nonverbal communication, speaking in the classroom must be good communicating and effect of communication is to improve students ability, because enthusiasm students depends on how the teachers using the utterances in classroom.

In education, especially in learning process in the class, before the teachers begin the lesson, they have to know and understand how the situation in the class, To create a fun learning, good communication is needed between teachers and students. Besides that, a teacher have to gives some message or advice to their students. Then the importance of Pragmatics studies how language is used by english teacher in real contexts, in spoken discourse in the classroom.

Pragmatics is the study of language usage. pragmatics is the study of those relations between language and context that are grammaticalized, or encoded in the structure of a language from it (Levinson, 1983, p. 9). It concerns with how utterances can have certain meanings in a certain situation and context. This research focuses on directive utterance. It will be analyzed using language form and speech act theory includes locution, illocution, and perlocution.

Pragmatics is one of branches in linguistics. It covers some topics. One of those topics is speech act. Searle (in Wijana and Rohmadi, 2011, p. 21) purposes that a speaker can perform three act simultaneously, that is locutionary act (the act of saying something), illocutionary act (the act of doing something) and perlocutionary act (the act of affecting someone). Searle (in Fauziati, 2009, p. 12) purposes five classes of speech acts, They are representative, expressive, commissives, declaratives, and directives. Directives utterance is an utterance that speaker wants hearer to do something. Types of directive utterances are requesting, warning, commanding, and suggestion, It can be found many directive utterances in real life for example

The teacher has just finished explaining the materials in the class that on that day. Before the teacher closed the class, the teacher said to the students that they have homework. So, the teacher said:

Teacher: Okay students, let's close our lesson. I will give you homework. Please make one text about explanation with free topic.

Locution: the teacher commands to the students in the classroom to make a text of explanation with free topic as the student's homework. 
Illocution: this utterance belongs to commanding utterance. The utterance given is imperative sentence. The teacher says to the students that the students have a homework. The homework is making a text of explanation with free topic. The materials of explanation text have just been given by the teacher in the class. In this case, the speaker is the teacher who gives a command, and the hearer is the students in the class who should do the command.

Perlocution: (the students maybe do the homework)

Yet, not all commands are in the form of imperative sentence. And not all requests are in the form of interrogative sentence. These all are going to be discussed more in this research. In the classroom, the teacher and students do communicate each other to get their purposes. One of communication that done by teacher is directive speech acts.

In speech act theory, Charles W Kreidler (1998) directives are defined as the speaker's act which attempt to make the addressee do, or sometimes not do, something. Despite different forms which they may take, directives are typically expressed by imperatives. And the speaker generally expects compliance on the part of the hearer. In classrooms, too, teachers do use directives and prospect students' compliance. In this connection, Tapper (1994) discusses the possible undesirable consequence of students not following Teachers directives sentences. He points out that in school settings, students would be punished in case they don't follow directives whereas, in colleges, they understand that following directives would help them to accomplish the task properly.

Directive utterance can be uttered by different ways. Grammatically, directive utterance can be in the form of declarative sentence, interrogative sentence, or imperative sentence. Furthermore, people have different intention by uttering directive utterance. The speaker's intentions can be command, request, prohibition, suggestion, warning, and invitation.

Although directives, in essence, expect a non-verbal behavior from the hearer, it is of fundamental importance for the speaker to choose among different forms of directives, the one which suits the circumstance best and furthermore, poses the least possibility of offense to the hearer(s), or to use Brown and Levinson's (1987) term, not to pose a face that is threatening act. In other words, the speaker has to express his intention appropriately with regards to the hearer's age, rank, and sex, among others. Hence, directives, like other types of speech acts, may be expressed in various forms. They may be expressed, for example, in the forms of imperative, interrogative, and declarative. Furthermore, they may be phrased in the forms of command, condition, and even wish as mentioned by Bolinger (1967, cited in Tapper, 1994).

According to the observation and analysis, the researcher decided to conduct the research on directives speech act spoken by the teacher responses in the teaching and learning process. Therefore, this research entitled : A Pragmatic Analysis of Directive Utterence Used by English Teacher at Madrasah Aliyah Pondok Pesantren Al-Kamil in the Academic year of 2019/2020.

\section{B. THEORETICAL STUDY}

\section{PRAGMATIC}


Pragmatics is the study of how to use language in communication. Pragmatics is also one of the fields in linguistics that studies about meaning. The meaning studied in pragmatics is influenced by contexts. This is in line with Brown and Yule (1983, p. 26) who state that pragmatics is the discussion of linguistics that involves the considerations of contexts. In other words, it can be said that, in pragmatics, the meaning of a particular expression is various depending on its context. Pragmatic is concerned with the study of meaning as communicated by speaker (or writer) and interpret by a listener (or reader). It has consequently, mean by their utterances that what the words by them selves. pragmatics is study of speaker meaning. Brown and yule (1996, p. 3).

\section{SPEECH ACT}

Speech act theory states that the action performed when an utterance is produced can be analyzed in three levels; they are locutionary act, illocutionary force, and perlocutionary effect (Cutting, 2002, p. 30). It is different with Austin's opinion which says that there are kinds of speech act, they are locutionary act, illocutionary act, and perlocutionary act. Actually their theory has the same meaning but they mention it in the different terms. Yule, (1996, p. 47) also gives the definition about speech act which says that it is the actions performed via utterances. His theory has the same meaning with the theories which are stated before but he adds that in English, speech act given more specific labels such as apology, compliment, and etc.

\section{DIRECTIVE}

Based on Yule (1996: 53), he classified directive speech act into some types, likes command/order, request, invitation, suggestion. Warning, \& prohibitation. Those types can be described as follow :

1. Command/order

A command is effective only if the speaker has some degree of control over the actions of the addressee. (Kreidler, 1998, p. 190). Command/order is the action done by the speaker who has the right or duty to give command to hearer. The speaker has a full authority on the act of the hearer. A command is more commonly known as imperative.

e.g. : Do the task!

2. Request

A request is an expression of what the speaker wants the addressee to do or refrain from doing (Kreidler, 1998, p. 190). Request is a kind of directive speech act whose its purpose is to get hearer to do something in circumstances in which it is not obvious that he/she will perform the action in the normal course of events (Searle 1969). By initiating request, the speaker believes that the hearer is able to perform an action.

e.g.: can you help me to do this project?

3. Suggestion 
Suggestions are the utterances we make to other persons to give our opinions as to what they should or should not do (Kreidler, 1998, p. 191). Suggestion is the process by which one thought leads to another, especially through association of ideas. It is related to something that should be done by the hearer. The utterances is transferred to the hearer in tactful way, so the utterances will not make the hearer being offended.

e.g.: How if you change the dialogue?

\section{Invitation}

Searle (1976) classifies invitations as directives, whose illocutionary point is that the hearer does a future action. For invitations, the future action is that the hearer comes to an event. By initiating an invitation, the speaker wants the hearer to come to a future event.

e.g.: Would you come to my house tonight?

5. Warning

Warning is telling someone about possible danger or difficulty. Warning usuall stated by positive imperative which give positive treatnment of effect. e.g.: No cheating!

6. Prohibition

Prohibition is giving order to to someone not to do something. Prohibition fumction is to forbid or prevent doeone from doing something. Prohibition is usually stated by using negative imperative without giving threat to the hearer. e.g.: Don't use that word!

According to Kreidler, (1998:192) directive utterence can be indicated by For a command to be felicitous the addressee must accept the speaker's authority; for a request, the speaker's wishes, and for a suggestion,the speaker's judgement.

In line with the statements above, the researcher can conclude that indicators of directive utterence from english teacher as follows :

According to Kreidler (1998) classification of directive utterences of english teacher based on indicators below :

Table 1. Indicatos of Directive Utterance

\begin{tabular}{|c|c|c|}
\hline No. & $\begin{array}{c}\text { Directive Speech } \\
\text { Act }\end{array}$ & Indicators \\
\hline 1. & Command/ Order & $\begin{array}{l}\text { They have the form You must... or they are } \\
\text { imperative sentences usually found is ending a full- } \\
\text { stop/period (.) or an exclamation mark/point (!) and } \\
\text { Imperatives can also be used with words like "please" } \\
\text { or "kindly" to add politeness. }\end{array}$ \\
\hline 2. & Request & $\begin{array}{l}\text { In such sentences, can and could be used to make } \\
\text { requests. }\end{array}$ \\
\hline
\end{tabular}




\begin{tabular}{|l|l|l|}
\hline 3. & Suggestion & $\begin{array}{l}\text { Modal verbs 'should' and 'ought to' are used to give } \\
\text { suggestions, } \\
\text { advice, and recommendations }\end{array}$ \\
\hline 4. & Warning/prohibition & $\begin{array}{l}\text { Its started by the word "dont" in the initial part of } \\
\text { sentence }\end{array}$ \\
\hline 5. & Invitting & $\begin{array}{l}\text { a mention of a time and/or place for a future event, an } \\
\text { assessment of the hearer's availability from searle } \\
(1976)\end{array}$ \\
\hline
\end{tabular}

\section{RESEARCH METHOD}

In this research, the researcher uses qualitative research with descriptive qualitative research method., the researcher presents the results of the research, namely the data analysis with transcript conversation between teacher and students which is used when the researcher did a research. The researcher presents the result of data collection administrated on 31 August 2020 at the XI class of Madrasah Aliyah Pondok Pesantren Al-Kamil. For collecting the data, researcher do observation and recording the learning process.

The researcher analyzes the directive speech act in this research using Kreidler's theory (1998). Based on the observation, the researcher found three types of directive speech act. They are command/order, request and warning. The types of directive speech act taken from utterances used by teacher in clasroom.

\section{RESEARCH FINDING AND DISCUSSION}

The dirrective utterance results are 3 utterances are command/order $(2,80 \%), 2$ utterances are requesting $(1,87 \%), 1$ utterance is warning $(0,93 \%)$, and 101 utterances are unidentified $(94,39 \%)$. The teacher's directive utterances shown in the chart below:

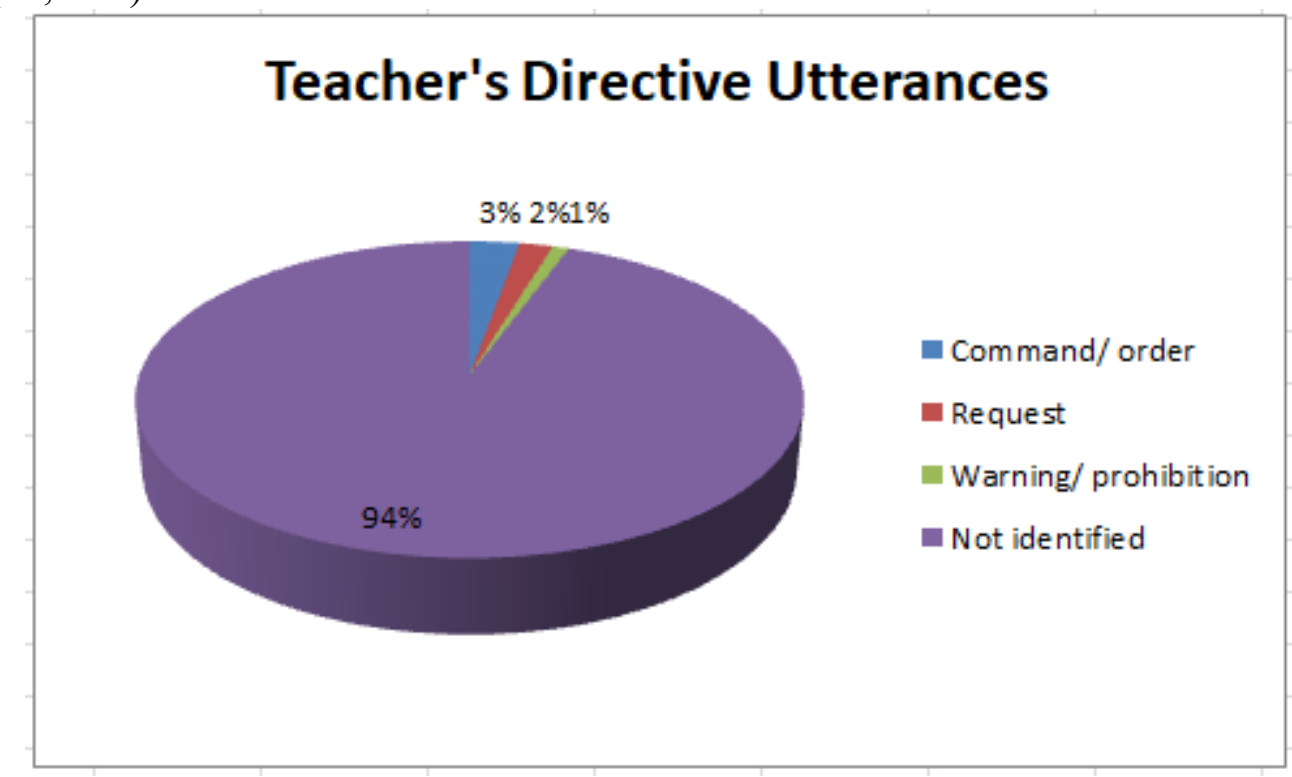




\section{1) Command / Order}

A command is effective only if the speaker has some degree of control over the actions of the addressee. (Kreidler, 1998, p. 190). Command/order is the action done by the speaker who has the right or duty to give command to hearer. The speaker has a full authority on the act of the hearer. A command is more commonly known as imperative. There are 3 utterances that found by the researcher $(2,80 \%)$ as follow:

Table 4. 1

Command/ Order Utterances

\begin{tabular}{|c|c|c|}
\hline No. & Coding & Utterance \\
\hline 1. & M1/12 & Open your text books please ! \\
\hline 2. & M1/68 & so please write it on your book. \\
\hline 3. & M1/83 & Please sit down siti khoirunnisa. \\
\hline
\end{tabular}

2) Request

A request is an expression of what the speaker wants the addressee to do or refrain from doing (Kreidler, 1998, p. 190). Request is a kind of directive speech act whose its purpose is to get hearer to do something in circumstances in which it is not obvious that he/she will perform the action in the normal course of events (Searle 1969). By initiating request, the speaker believes that the hearer is able to perform an action. There are 2 utterances that found by the researcher $(1,87 \%)$ as follow :

Table 4. 2

Request

\begin{tabular}{|l|l|l|}
\hline No. & \multicolumn{1}{|c|}{ Coding } & \\
\hline 1. & M1/57 & Can you translated ? \\
\hline 2. & M1/84 & Who can write on white board one of you ? \\
\hline
\end{tabular}

3) Warning

Warning is telling someone about possible danger or difficulty. Warning usuall stated by positive imperative which give positive treatnment of effect. Its started by the word "dont" in the initial part of sentence. There are 1 utterances that found by the researcher $(0,93 \%)$ as follow : 
Table 4. 3

Warning

\begin{tabular}{|l|l|l|}
\hline No. & \multicolumn{1}{|c|}{ Coding } & \multicolumn{1}{c|}{ Utterances } \\
\hline 1. & M1/81 & Dont write to big because maybe there will be more than one \\
\hline
\end{tabular}

4) Unidentified utterances

According to utterances teacher in learning process, there are some data show as unidentified utterances based on indicators theory Kreidler. There are 101 utterances that found by the researcher $(94,39 \%)$. As examples some data coding as follow :

Table 4. 4

Unidentified

\begin{tabular}{|l|l|l|}
\hline No. & \multicolumn{1}{|c|}{ Coding } & \\
\hline 1. & M1/08 & I would like to give you some dialogue ya \\
\hline 2. & M1/09 & That show as about giving advice yaa \\
\hline 3. & M1/10 & Here there are three dialogue \\
\hline 4. & M1/11 & And then we're going to read them but before that everyone of \\
& & you \\
\hline
\end{tabular}

The discussion are arranged in order to answer the problem statements of the research. In the research findings above consists of classification of directive speech act including the context situation \& the meaning. Researcher attempted to explain the types \& utterances meaning of directive speech at used by english teacher of Madrasah Aliyah Pondok Pesantren AL-Kamil using Kreidler (1998) theory.

A command is more commonly known as imperative. A command is one of the types of the directive act found in teacher utterances in learning process. A command is used to give orders or exert authority toward someone or something. The usual function of a command/imperative sentence is to give a command or instruction. It tells us to do something. Command sentences are used when people are telling someone to do something or not to do something.

Command/ order is effective only if the speaker has some degree of control over the actions of the addressee. (Kreidler, 1998, p. 190). taken from the list of command/ order utterance is coding M1/12 :

Table 4. 5

Command/order

\begin{tabular}{|l|l|}
\hline Coding & Utterance \\
\hline
\end{tabular}




\begin{tabular}{|l|l|}
\hline M1/12 & Open your text books please ! \\
\hline
\end{tabular}

The utterance above show that the utterances contain the directive speech act. When you write instructions telling somebody how to do something, we can also use commands. Commands usually start with an imperative verb, also it is known as a 'bossy verb' because they tell someone to do something. The typical form (structure) of an English imperative sentence uses the base verb. From this utterance above, the final punctuation is usually found is ending an exclamation mark/point (!). also be used with words like "please" or "kindly" to add politeness.

Another utterance is coding M1/68 :

Table 4. 6

Command/order

\begin{tabular}{|c|c|}
\hline Coding & Utterance \\
\hline M1/68 & So please write it on your book. \\
\hline
\end{tabular}

The utterance above show that the utterances contain the directive speech act. This utterance from teacher contained directive utterance command/order. From utterance above teacher order to students to write material study in their book. According to kreidler (1998) command/order is if the speaker has some degree of influence over the behavior of the addressee, it is successful called command/order. And the spesific sign from this research according to indicators this utterance contained politeness " Please".

Another utterance is coding M1/83

Table 4.7

Command/order

\begin{tabular}{|c|c|}
\hline Coding & Utterance \\
\hline M1/83 & Please sit down siti khoirunnisa. \\
\hline
\end{tabular}

From the above example, data coding M1/83 above show teacher order the students to should sit on their seats again. The word please sit down is a word of command to students, and this is imperative sentences and Imperatives can also be used with words like "please" or "kindly" to add politeness. they are imperative sentences usually found is ending a full-stop/period (.).

A request is an expression of what the speaker wants the addressee to do or refrain from doing (Kreidler, 1998, p. 190). Request is a kind of directive speech act whose its purpose is to get hearer to do something in circumstances in which it is not obvious that he/she will perform the action in the normal course of events (Searle 1969). By initiating request, the speaker believes that the hearer is able to perform an action. taken from the list of request utterance is coding M1/57 : 
Table 4. 8

Request

\begin{tabular}{|c|c|}
\hline Coding & Utterance \\
\hline M1/57 & Can you translated $?$ \\
\hline
\end{tabular}

A request is one of the types of directive acts found by researcher in this research in teacher utterances in learning process. The request is the act of asking for something to be given or done, especially as a favor or courtesy; solicitation or petition. Here, the speaker attempts by the speaker to get the address to do something. Moreover, a request is an expression of what the speaker wants the addressee to do or refrain from doing.

From the above example, data coding M1/57 above show the directive act of request. Here, the speaker attempts by the speaker to get the address to do something. The modal 'can' be a commonly used modal verb in English. It is used to express; ability, opportunity, a request, to grant permission, to show possibility or impossibility. When we make requests, we can use can. In such sentences, can and could be used to make requests. The sentence is structured as a question so as to indicate that you are leaving it at the other person to decide if he wants to help you. We often use can or could to ask people to do things.

Another utterance is coding M1/84

Table 4. 9

Request

\begin{tabular}{|c|c|}
\hline Coding & Utterance \\
\hline M1/84 & Who can write on white board one of you ? \\
\hline
\end{tabular}

From the above example, data coding M1/84 above show the directive act of request. Here, and also the speaker attempts by the speaker to get the address to do something. The modal 'can' be a commonly used modal verb in English. When teacher make request to students, teacher using modal verb is "can".

Warning is telling someone about possible danger or difficulty. Warning usuall stated by positive imperative which give positive treatnment of effect. (Yule, 1996). Teacher sometimes, these utterances are used in teaching learning processes to alert students if they make errors, such as making noise in the lesson, violating the code, or putting their assignment in the incorrect formula or tenses. The role of alert is to make the students in the classroom more conscious \& disciplined. taken from the list of warning utterance is coding M1/81 :

Table 4. 10

Warning/prohibiton

\begin{tabular}{|c|c|}
\hline Coding & \multicolumn{1}{|c|}{ Utterance } \\
\hline M1/81 & Dont write to big because maybe there will be more than one \\
\hline
\end{tabular}


From the above example, data coding M1/81 above show the directive act of warning. According to indicators of this research warning Its started by the word "dont" in the initial part of sentence. This utterance contained word "dont" in sentences and this utterance also to warn students dont write to big on whiteboard because the other students will be wrote in some space in whiteboard.

Furthermore in this research, after researcher classify utterances from data researcher found there are some data unidentified based on indicators According to utterances teacher in learning process, some data show as unidentified utterances based on indicators theory Kreidler. Researcher will shows some data unidentified, taken from the list of unidentified utterance is coding M1/08 :

Table 4. 11

unidentified

\begin{tabular}{|l|l|}
\hline M1/08 & I would like to give you some dialogue ya \\
\hline M1/23 & Good well before we move to the next dialogue ar the dialogue two \\
\hline M1/24 & Lets look to the dialogue \\
\hline M1/32 & Do you need any help, what for is it \\
\hline
\end{tabular}

From the above example, data coding M1/08, M1/23, M1,24, M1/32 stated unidentified because if according to indicators from kreidler (1998) researcher didnt found relation with indicators of this research.

Therefore from unidentified data there are 101 utterances that found by the researcher. The researcher presents the all of unidentified data of the research in appendix I.

So it can be concluded that the result of the research shows that most of utterences from english teacher at Madrasah Aliyah Pondok Pesantren AL-Kamil non sequentially, because the highest number of utterences from teacher is used command/ order. The second some utterences from teacher is request and the last utterence from teacher is warning. then it can be concluded that the teacher's directive utterences in the class mostly used commands/order .

\section{E. CONCLUSION}

Based on the data analysis on the previous chapter, There are three types of directive speech acts used by the English teachers at Madrasah Aliyah Pondok Pesantren AL-Kamil. They are command/order, requesting, \& warning/prohibition. Almost all of types directives speech act teacher use it with average number. The purpose of the speech act of the Teacher Directive can not be separated from the situational context. In addition, the teacher-student relationship often becomes another factor in understanding why the teacher implements such a directive. The object of the teacher's directives in teaching learning is divided into five. First, command/order, This directive was used by teachers to show their credibility in the classroom in order to make students do what they want. This statement is used by teachers to direct or educate students about what they have to 
Globish (An English-Indonesian journal for English, Education and Culture

Vol. 10, No.2, July 2021,

P-ISSN: 2301-9913, E-ISSN: 2597-9132

DOI: http://dx.doi.org/10.31000/globish.v7i2

do in the classroom. For teachers to perform a successful teaching learning process by asking students to be active, this statement is important. Second, request, teacher used to ask or order student to do something in indirect or polite way. Teachers use requests in classroom instruction, not only to tell the students something, but the teacher often plans to do something that the teacher needs to do. Third, suggest, teacher used this directive in explaining \& discussing the lesson material in teaching learning to give students option or alternative in order to make them easier understanding the material. Teacher also used this expression to give the students suggestion about what act or way they should take for their own benefit. Fourth, Warning, In classroom activity, teacher employ this utterances to giving warn to student to keep them safe from danger that maybe caused by their action, like giving warn about the mistakes \& consequences if they wrong write formula of sentence, student who break the rules or not obeying teacher command, etc. Fifth, inviting, In classroom teaching learning, teacher used "inviting" directive as guidance or stimulus for students to involving in learning process. By involvement student, the teaching learning process will become interactive $\&$ more effective. This utterances also has purpose to make students being active in classroom to create teaching learning effectiveness.

\section{REFERENCES}

Brown, Gillian dan George Yule. 1996. Analisis Wacana. Jakarta: Gramedia Pustaka Utama.

Brown, P. and Levinson, S. (1987). Politeness: Some Universals in Language Usage. Cambridge: Cambridge University Pess.

Ervin_Tripp, S. (1976). Is Sybil there? The Structure of Some American English Directives. Language in Society, 5, pp. 25_55.

Jones, K. (1992). A question of context: Directive use at a Morris team meeting. Language in Society, 21, pp. 427_445.

Kreidler, Charles W.1998. Introducing English Semantics. London : Library Congress Catalouging.

Leech, Geoffrey. Oka, M.D.D. (Penerjemah). 1993. Prinsip-prinsip Pragmatik. Jakarta: Universitas Indonesia Press.

Ibrahim, A. S. (1993). Kajian Tindak Tutur. Surabaya: Usaha Nasional.

Sinclair, J. \& Coulthard, R. M. (1974). Toward an analysis of discourse. London: Oxford University Press.

Searle, J. R. (1969). Speech acts. Cambridge: Cambridge University Press.

Tapper, J. (1994). Directives used in college laboratory oral discourse. System, pp. 205_222. Tsui, Amy B. M. (1995). English conversation. Oxford University Press. 
Globish (An English-Indonesian journal for English, Education and Culture

Vol. 10, No.2, July 2021,

P-ISSN: 2301-9913, E-ISSN: 2597-9132

DOI: http://dx.doi.org/10.31000/globish.v7i2

Afifuddin, B. A. (2009). Metodologi Penelitian Kualitatif, . Bandung: Pustaka setia.

Arikunto, S. (2010). Prosedur Penelitian: Suatu Pendekatan Praktek edisi revisi. Jakarta: PT Rineka Cipta.

Bach, K. (1994). Mind \& Languange. San Fransisco: Blackwell Publishing Ltd.

Bach, K. (2015, November 30). Meaning and Communication. Retrieved from Routledge

Encyclopedia of Philosophy: http://userwww.sfsu.edu/ kbach/Bacp.Meaning\&Communication.pdf

Brown, G., \& Yule, G. (1983). Discourse Analysis. New York: Cambridge University Press.

Cutting, J. (2002). Pragmatic \& Discourse. London \& New York: Rouletdge.

Holmes, J. (1992). An Introduction to socolinguistics. London: Longman Group UK Limited.

Levinson, S. C. (1983). Pragmatics. New York: Cambridge University Press.

Matthew, M. B., \& Huberman, A. M. (1994.). Qualitative Data Analysis,2nd Edition. California: Sage Publication.

Mey, J. (1993). Pragmatic : An Introduction. Cambridge: Blackwell Publisher.

Mey, J. L. (2001). Pragmatics: An Introduction, 2nd Edition. Maldon: Blackwell.

Moleong, L. J. (2004). Metodologi Penelitian Kualitatif, Edisi Revisi. Bandung: Remaja Rosdakarya.

Morse, J. M. (1994). Critical Issues in Qualitative Research Methods. Utah: University of Utap.

Retnaningsih, W. (2007). Hand Book of Research Writing. Salatiga: STAIN SALATIGA PRESS.

Searle, J. R. (1969). Speech acts: An essay in the philosophy of language. Cambridge: Cambridge university press.

Seliger, P. W. (1989). Second language research methods. Oxford: Oxford University Press.

Sugiyono. (2012). Metode Penelitian Pendidikan: Pendekatan Kualitatif, Kuantitatif, dan R\&D. Bandung: Alfabeta.

Tsui, A. B. (1994). English Conversation : Describing English Language. California: Oxford University Press. 
Globish (An English-Indonesian journal for English, Education and Culture

Vol. 10, No.2, July 2021,

P-ISSN: 2301-9913, E-ISSN: 2597-9132

DOI: http://dx.doi.org/10.31000/globish.v7i2

Wijana, D. P. (1996). Dasar-Dasar Pragmatik. Yogyakarta: Andi Offset. 